International Journal of Engineering \& Technology, 7 (4) (2018) 2499-2505
International Journal of Engineering \& Technology
SPC
Website: www.sciencepubco.com/index.php/IJET
doi: $10.14419 /$ ijet.v7it.12287
Research paper

\title{
Comparative phytotoxicity of Azolla pinnata and Lemna minor in Treated Palm Oil Mill Effluent
}

\author{
Azlin Binti Abd Kadir ${ }^{1}$ *, Siti Rozaimah Sheikh Abdullah ${ }^{1}$, Hassimi Abu Hasan ${ }^{1}$ \\ ${ }^{I}$ Research Centre for Sustainability Process Technology (CESPRO), Faculty of Engineering and Built Environment, University \\ Kebangsaan Malaysia, 43600 UKM Bangi, Selangor, Malaysia. 2Chemical Engineering Program Faculty of Engineering \\ and Built Environment, University Kebangsaan Malaysia, 43600 UKM Bangi, Selangor, Malaysia \\ *Corresponding author E-mail: azlinabdkadir@gmail.com
}

\begin{abstract}
The phytotoxicity of Azolla pinnata and Lemna minor was assessed when exposed To Treated Palm Oil Mill Effluent (POME) for their survival and growth tolerance in a 5-day exposure conducted in an open laboratory at Universiti Kebangsaan Malaysia. A total of 34100 $\mathrm{mL}-$ containers were used, with three replicates for each concentration, including plant less control and plant control. $50 \mathrm{~mL}$ of treated POME in different concentrations (100\%, 75\%, 50\% and 25\%) was filled in each container and exposed to $3 \mathrm{~g}$ Azolla pinnata or Lemna minor with observation conducted daily. After two days of exposure, $40 \%$ of A. pinnata died in $100 \%$ concentration and almost $100 \%$ died after 5 days of exposure for all concentrations. On L. minor, only 5\% mortality was observed for 100\% concentration on the fourth day and remained healthy until the end of five days. At the end of 5-day phytotoxicity exposure, the highest removals were $63.0 \%$, $70.5 \%, 51.0 \%, 65.4 \%$ and $53.8 \%$ respectively for COD, BOD, Ammonia, Phosphate And Nitrates by A. pinnata, while the maximum removals recorded by $L$. minor were $61.0 \%, 54.0 \%, 9.8 \%, 61.4 \%$ and $31.6 \%$ respectively, giving evidence that $A$. pinnata is more effective in removing pollutants than L. minor although its survival in the treated POME is lesser than L. minor.
\end{abstract}

Keywords: Azolla Pinnata; Lemna Minor; Phytotoxicity; Palm Oil Mill Effluent (POME,

\section{Introduction}

Malaysia is one of the major producers of crude palm oil, besides Indonesia, in the world which accounted for $31.9 \%$ in 2016 [1] Total revenue of the world's palm oil is expected to rise again in 2017 over the previous years due to a recovery in the palms after the effects of El Nino, which occurred in 2016 [2]. The highest production statistics of selected food crops in Malaysia is also on the production of palm oil compared to rice, natural rubber, cocoa and kenaf, to an increased production of palm oil by $2.4 \%$ in 2015 [3] The increase of oil palm products in Malaysia will also in creasingly generate wastewater from palm oil mills each year. Palm oil production process requires large volume of water with approximately 5-7.5 tons of water is required to produce 1 ton of palm oil and $50 \%$ of that water will contribute to the generation of wastewater [4] which is also commonly known as palm oil mill effluent (POME). Basically, palm oil processing will produce wastewater during sterilization, separation of sludge and also during cyclone process. Typically, oil palm wastewater is treated in several stages involving few processes of cooling pond, anaerobic, aerobic and final discharge. Many POME treatment schemes currently used by the Malaysian palm oil industry including membrane bioreactor and biological method were discussed in details by [5-7]. However, the application of these technologies is often still difficult to comply with the stringent environmental regulation in Malaysia. Phytoremediation, a fairly new technology in tropical country like Malaysia, is proposed to further polish treated POME which is still rich with nutrients and most of the time hardly meets the stringent environmental regulation, using native ferns that are later to be used as livestock feeds. Phytoremediation is one of the green technology processes utilizing plants to reduce the concentration of pollutants in contaminated soil, water or air using plants or herbs that attempt to control, degrade, or remove metals, pesticides, solvents, cracking materials, crude oil, and various contamination materials [8]. It is low cost, easy to handle and environmental friendly that make use of plants together with microorganism to remove or detoxify contaminations in wastewater [9-12]. More than 500 species of plants are listed as a potential plant for phytoremediation [13], most of them are temperate plants. One of this research output is to identify tropical and native plants in Malaysia that can be used to further polish palm oil mill effluent as well as later be used as livestock feeds. Phytoremediation technology has been widely used to treat various industrial wastes but not much for POME. There are studies utilizing floating plants or duckweeds to treat POME, due to the fact that the properties of the floating plants themselves are easy to multiply and efficient to treat pollutants [14]. In addition, Eichhornia crassipes can also reduce COD up to $33-45 \%$ in POME after 6 days of study [15]. [16] had applied emergent plants of Vetiver and found that Vetiver was able to reduce COD and BOD up to $70.60 \%$ and $93.33 \%$ in pure POME. Other plants such as Pistia stratiotes [17], Lysia oryzoides [18] and Ludwigia peploide [19] are also able to reduce COD in POME up to 39.1-59.66\%, $27 \%$ and $20 \%$, respectively. Therefore, the uses of other types of duckweeds and, emergent and submerged plants are still further explored to be used for POME treatment by considering their capabilities in pollutant removal, survival and their tolerance in the effluent. In this study, two types of duckweed, Azolla pinnata and Lemna minor were selected to polish treated POME so that at the 
end they can be converted to be livestock feed for fish, chickens and ducks. Both are native aquatic and floating ferns that can be used to treat domestic [20] and industrial wastewater [21-23]. Both of these ferns are considered as duckweed, with the duckweed dispersal worldwide is due to the adaptation of plants that lead to different species [24]. Duckweed is a plant with fast reproduction and can absorb a large amount of nutrients such as Nitrogen $(\mathrm{N})$ and Phosphorus $(\mathrm{P})$ from agricultural and municipal [2529]. L. minor consists of small-sized monocotyledon plants floating on a calm surface of the pond [30-31]. Its plant structure is relatively simple and only consists of leaves and roots [24]. Among different plant-based systems, L. minor has been applied with success in different countries for the removal of nutrients and heavy metals, combining efficient wastewater treatment and important biomass production [11-32]. A. pinnata is also a floatingfree aquatic plant belonging to the Azollaceae family. It is widely distributed in Asia and along the tropical African coast [33]. It has one cavity in the center of the leaf, which hosts symbiotic cyanobacteria, Anabaena azollae [34]. This symbiont absorbs $\mathrm{N}_{2}$ from the atmosphere and produces high nitrogen levels in the A. pinnata plant tissue, creating the plant to be useful as a green manure where it has been used for several centuries [35-37], [22]. Some advantages for Azolla is it can grow rapidly and double its biomass in every three days. It produces more than 4 to 5 times the protein compared with hybrid Napier and Lucern [38]. There are at least eight-azolla species worldwide which is A. caroliniana, $A$. circinata, A. japonica, A. mexicana, A. microphylla, A. nilotica, A. pinnata and A. rubra. Species of A. pinnata and A. microphylla are usually found in Malaysia. They can grow naturally on calm waterways like abandoned rivers, canals and ponds [39]. Both of these plants are also able to absorb heavy metals found in wastewater [40-41]. This study aims to determine the tolerance and survival of these two plants (A. pinnata and L. minor) in treated POME as to select the right concentrations of POME to be used in the next stage of plant uptake in larger scale (pilot scale) by these plants in treated POME.

\section{Materials and method}

\subsection{Plant collection and propagation}

The two healthy and fresh plants, A. pinnata and $L$. minor were obtained from a greenhouse at Universiti Kebangsaan Malaysia. The plant was cultured in Hoagland medium as suited by [42-43] to ensure plant stock is sufficient for future research activities. Some plants were taken and placed in a beaker filled with tap water and left for $10 \mathrm{~min}$ to remove the remnants attached to the plant roots. Then, the plants were washed with tap water, filtered and dried using tissue paper to reduce the percentage of water at the plant [44]. Both plants' growth was observed physically in terms of their colour change. Figure 1 compares an image of healthy $A$. pinnata and $L$. minor with the dead ones. Healthy $A$. pinnata is a dark green, while $L$. minor is light green (Figure 1). A. pinnata will change its color to dark brown while $L$. minor will change its green color to white when dies.

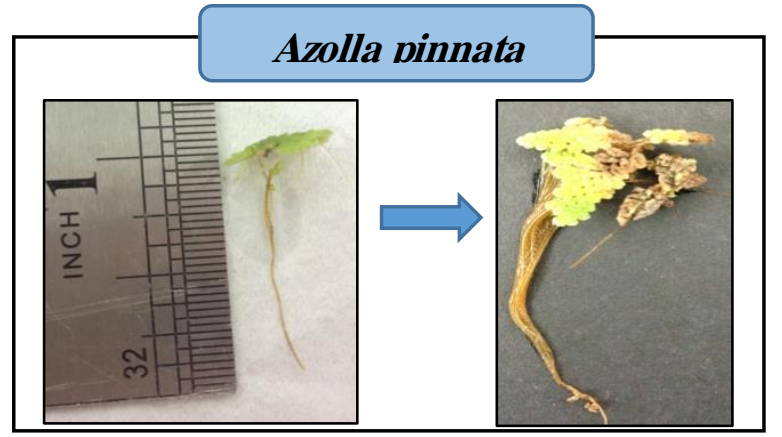

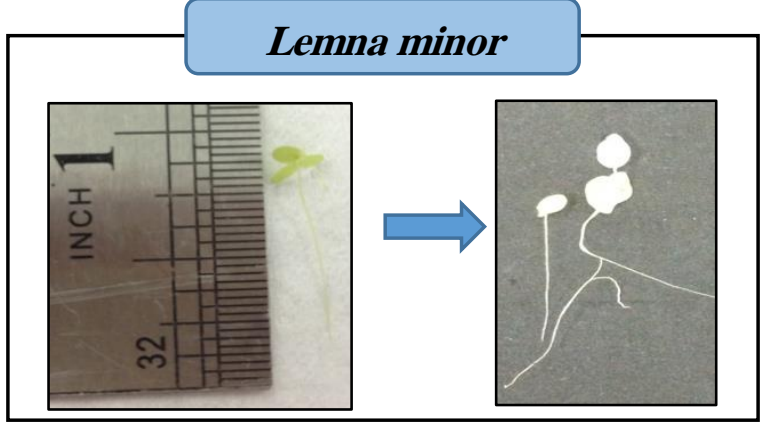

Fig. 1: Azolla Pinnata and Lemna Minor Discoloration when Healthy and after Death.

\subsection{Experimental design of phytotoxicity test}

The purpose of this study is to illustrate how duckweeds, which are small, simply constructed, floating aquatic plants, and suitable for dealing with toxicity [45]. The duckweed is able to grow rapidly in a solution containing high nutrients and potentially to reduce toxicity in waste solution. Under controlled conditions, the duckweeds test is excellent for determining the toxicity of water pollutants, and duckweeds are essential as a model of aquatic plants in Eco toxicity assessment [46]. [45] and [47] also discussed duckweed as a mechanism that can remove toxicity with the aid of additional nitrogen in which duckweed cultivation on nutrient-rich sewage has described the diversity and the potential of this plant for water recovery and for the remediative use of growth. To achieve this toxicity study, a total of $34100 \mathrm{~mL}$-containers were prepared for the phytotoxicity test. Sixteen containers were used for each plant (A. pinnata and L. minor). Each container contained $50 \mathrm{~mL}$ of treated POME obtained from a crude palm oil mill in Dengkil, Selangor with different POME concentration of $100 \%$, $75 \%, 50 \%$ and $25 \%\left[\left(\mathrm{~V}_{\text {treated POME }} / \mathrm{V}_{\text {total }}\right) \times 100 \%\right]$. For example, $75 \% \mathrm{v} / \mathrm{v}$ of treated POME was prepared by taking $37.5 \mathrm{~mL}$ of treated POME and adding $2.5 \mathrm{~mL}$ tap water to obtain $50 \mathrm{~mL}$ of solution. Table 1 lists down the characteristics of the treated POME obtained from the palm oil mill. Each dilution was triplicated and control solution was also provided for each dilution without the plants. Another container acting as plant control containing plants with $50 \mathrm{~mL}$ tap water. Each container was loaded with $3 \mathrm{~g}$ of L. minor or A. pinnata as illustrated in Figure 2.

Table 1: Characteristics of Treated Pome

\begin{tabular}{ll}
\hline Parameter & Value \\
\hline $\mathrm{COD}$ & $836 \pm 21 \mathrm{mg} / \mathrm{L}$ \\
$\mathrm{BOD}_{5}$ & $400 \pm 17 \mathrm{mg} / \mathrm{L}$ \\
$\mathrm{NH}_{4}-\mathrm{N}$ & $15.2 \pm 0.4 \mathrm{mg} / \mathrm{L}$ \\
$\mathrm{PO}_{4}{ }^{3-}$ & $13.7 \pm 0.5 \mathrm{mg} / \mathrm{L}$ \\
$\mathrm{NO}_{3}{ }^{-}$ & $28.0 \pm 12 \mathrm{mg} / \mathrm{L}$ \\
$\mathrm{pH}$ & $9.56 \pm 0.3$ \\
\hline
\end{tabular}

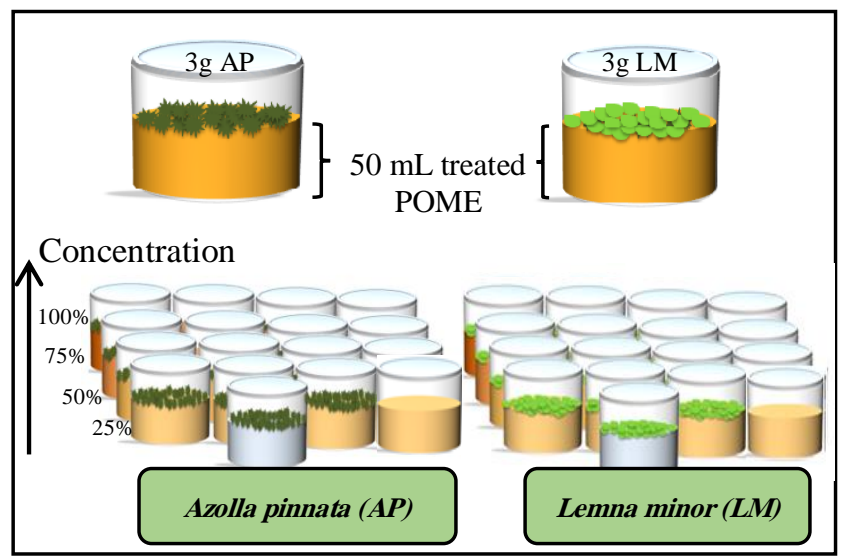

Fig. 2: Experimental Set-Up for Phytotoxicity Test. 


\subsection{Physical observation of plant}

Observations were made every day starting from day 0 to day 5 and quantified with the percentage of plants that can survive for each concentration of treated POME. Table 2 shows the physical indicator of A. pinnata and L. minor observed for healthy and dead ones. A. pinnata will turn brown from the center of the fronds and eventually become black when it dies. For L. minor, it turned white when died, as shown in Table 2. The tolerance and survival of both plants are quantified based on the area of the healthy ones compare to the total area covered by the whole fern on the water surface and also on the colour change.

Table 2: Indicator for Healthy and Dead Plants for Azolla Pinnata and Lemna Minor

\begin{tabular}{ccc}
\hline Plant & Fresh /Healthty & Dead \\
\hline $\begin{array}{c}\text { Azolla } \\
\text { pinnata }\end{array}$ & \\
\hline $\begin{array}{c}\text { Lemna } \\
\text { minor }\end{array}$ & \\
\hline
\end{tabular}

\subsection{Analysis of wet biomass and water quality parame- ters}

Physicochemical parameters of the treated POME, including total biomass, Chemical oxygen demand (COD), biological oxygen demand $\left(\mathrm{BOD}_{5}\right), \mathrm{pH}$, ammonia nitrogen $\left(\mathrm{NH}_{4}-\mathrm{N}\right)$, nitrate nitrogen $\left(\mathrm{NO}_{3}{ }^{-}\right)$, and dissolved orthophosphate $\left(\mathrm{PO}_{4}{ }^{3-}\right)$, were observed throughout the 5-day exposure. Experiments were initiated by analyzing POME for each dilution of 100, 75, 50 and 25\% and on each day of sampling, water samples were taken from each container for the analysis of water quality parameters. The plants were harvested each day 1, 3 and 5 for their growth characteristic namely wet biomass. The total biomass was analyzed by filtering plants using a $1 \mathrm{~mm}$ sieve [48] to instantly reduce the water content of the plant and weighed to obtain the wet weight of each sample [49]. The $\mathrm{pH}$ was measured with an IQ 150 Multiprobe (IQ Scientific Instruments, Spectrum Technologies, Plainfield, U.S.A and the rest of parameters were analyzed using the $\mathrm{HACH}$ test kits with an UV spectrophotometer (DR 6000, Hach Company, Loveland, CO, USA). All these water quality parameters were determined according to the Standard Methods [30].

\section{Results and discussion}

\subsection{Effect of treated pome on plant growth}

The ability of A. pinnata to survive in treated POME of different dilutions was observed throughout 5 day-exposure as shown in Table 3. No colour changes were observed on the first day of exposure. Unlike on the second day, only $60 \%$ of the plants survived in $100 \%$ treated POME (no dilution), but in $75 \%, 50 \%$ and $25 \%$ dilution, most plants in the containers were still alive and healthy. On the third day, only $30 \%$ of the plants were still green at $100 \%$ POME, while on the other dilutions it had shown a significant decrease. Physically, it can be seen on the fourth and fifth day that all the plants turned black and died indicating that $A$. pinnata failed to resist the toxicity of the treated POME solution. Moreover, the longer the exposure, the darker the colorization of the plant leading to invariably death of plants. [48] also showed $A z$ olla $s p$. plants could not withstand toxicity on remaining wastewater but [21] found that it is capable of treating heavy metals ( $\mathrm{Hg}$ and $\mathrm{Cd})$ in wastewater.

Table 3: Physical Observation of the Toxicity of Treated POME on Azolla Pinnata

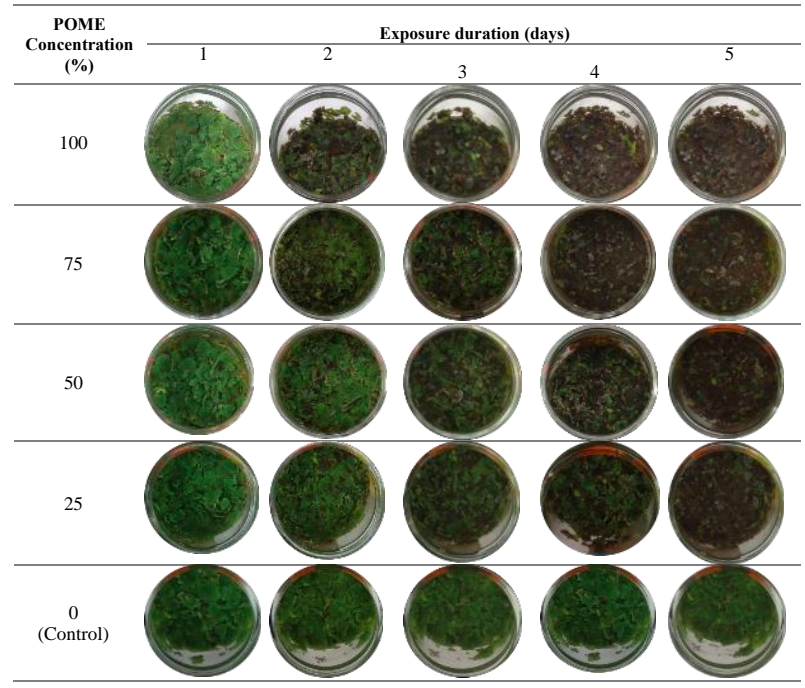

Similar amount ( $3 \mathrm{~g}$ ) of $L$. minor was also exposed to the treated POME with different dilution for 5 days. For $L$. minor, it was observed that healthy light green color of the plants remained unchanged until the third day of exposure (Table 4). The plants were still fresh in the all dilutions of treated POME (25\% up to $100 \%$ ). On day 4 , it was found that only $5 \%$ of the plants turned white indicating death signs in the $100 \%$ treated POME and remained the same until the end of 5-day exposure. This is proven that $L$. minor is highly resistant to toxicity even in $100 \%$ treated POME. [50] had also demonstrated the suitability of L. minor to treat final POME and, [51] also indicated the capability of this plant to treat laboratory wastewater.

Table 4: Physical Observation of the Toxicity of Treated Pome on Lemna Minor

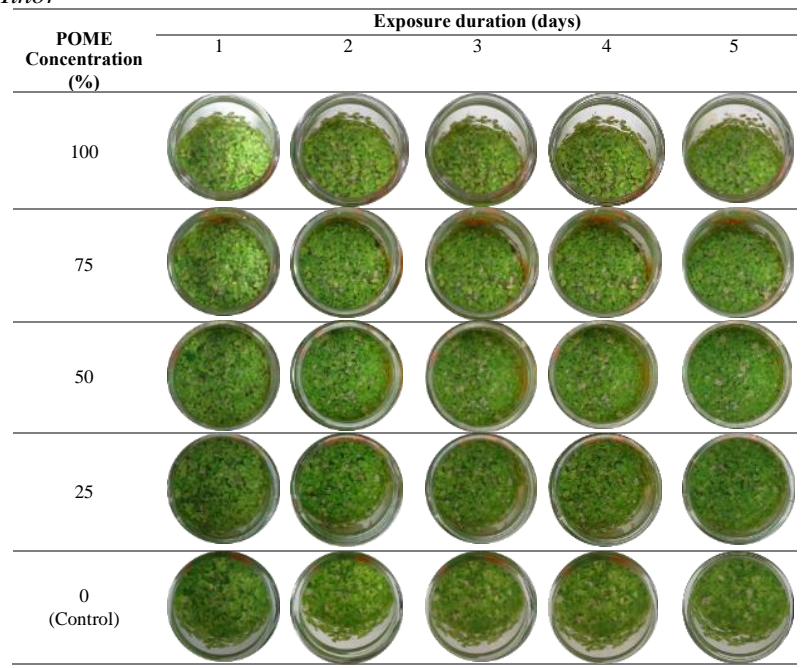

Figure 3 illustrates the wet biomass of both plants compared to the control plant throughout the 5-day exposure. The growth of $A$. pinnata increased on the first day and decreased with time until the fifth day. The wet biomass of $A$. pinnata in all the concentrations of treated POME decreased significantly compared to that in the plant control. Similar trend was observed on the physical growth of A. pinnata, as explained previously, in which the plants turned black, a sign of dead plants, starting the first day of exposure as shown in Table 3. This is because the plants cannot tolerate high nutrient content in POME solution. For L. minor, the 
growth of plants in all concentrations of treated POME did not show any significant effect compared to the control plants. The wet biomass of all plants increased on the first day and then gradually decreased until day 5 , following similar trend with the control plant. This result is in line with the physical growth as captured in Table 4. A study conducted by [52] also show similarity with the decrease of biomass volume for the study using synthetic hydrocarbon wastewater. In contrast to the study conducted by [50], the results showed an increase in the amount of biomass on the $L$. minor carried out at pilot scale.

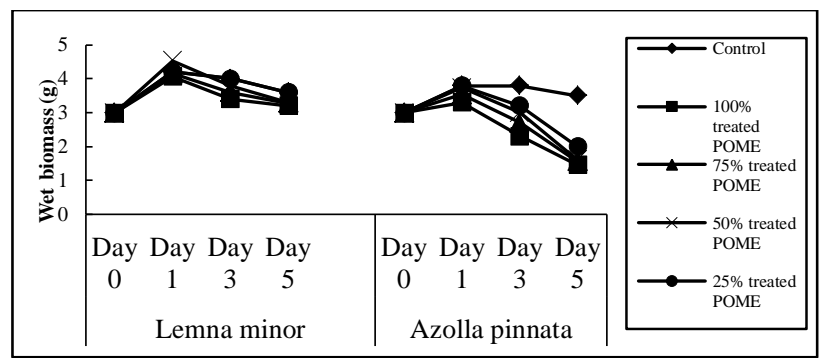

Fig. 3: Wet Biomass of Azzola Pinnata and Lemna Minor throughout the 5-Day Phytotoxicity Test to Treated POME.

\subsection{Comparative tolerance of Azolla pinnata and Lemna minor}

The physical observation for the plant tolerance and survival was quantified in terms of the number of plants that still remained fresh and green. Figure 4 clearly shows that $L$. minor has higher resistance $(95 \%)$ to the toxicity of treated POME with only $5 \%$ became white and died compared with $A$. pinnata. Up to day $5, \mathrm{~L}$. minor was still able to survive while $A$. pinnata started to die starting day 3 and mostly died on day 5 .

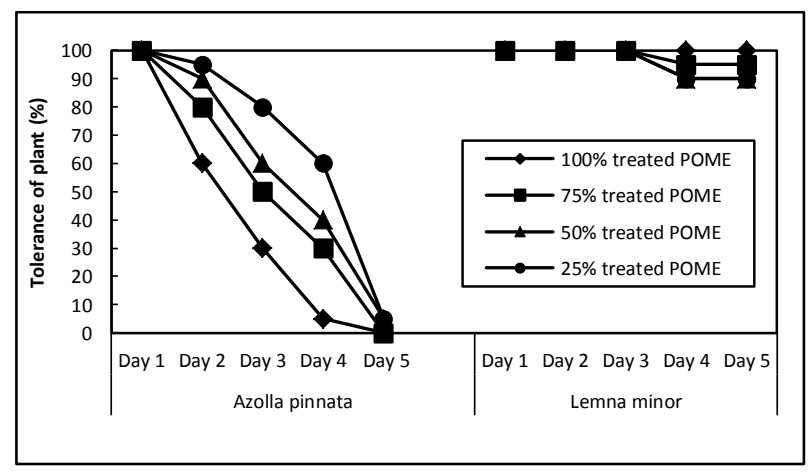

Fig. 4: Comparison on the Phytoxicity of Treated POME on Azolla Pinnata and Lemna Minor.

\subsection{Characteristics of wastewater throughout the 5-day exposure}

The results of water quality parameters $\left(\mathrm{NO}_{3}{ }^{-}, \mathrm{PO}_{4}{ }^{3-}, \mathrm{NH}_{4}-\mathrm{N}, \mathrm{pH}\right.$, $\mathrm{BOD}_{5}$ and COD) for POME were depicted in Figure 5. On nitrate content, it is found that the maximum nitrate removal of $53.8 \%$ is observed in the $100 \%$ treated POME for A. pinnata. While L. minor also showed a decline with a loss of nitrates to $13 \mathrm{mg} / \mathrm{L}$ which is $31.6 \%$ removal at $75 \%$ treated POME solution over a 5day trial. As well as, in $50 \%$ and $25 \%$ solutions, both plants showed a decrease to $5 \mathrm{mg} / \mathrm{L}$ for A. pinnata and $4 \mathrm{mg} / \mathrm{L}$ for $L$. minor. Overall, it shows that A. pinnata is a potential phytoremediator in all distributions. The reduction of nitrate-nitrogen in different wastewater was in agreement with previously reported study by [53] that $A$. pinnata can reduce the nitrate content up to $88 \%$ in the Hoagland solution, and achieve $100 \%$ nitrate reduction from the study solution using well water and sewage water. [51] reported that $L$. minor can remove nitrate from municipal wastewater, sewage water and seafood processing plant wastewater with 66 to $99 \%$ removal. Ammonia is a measure of water health in rivers, lakes, and groundwater.
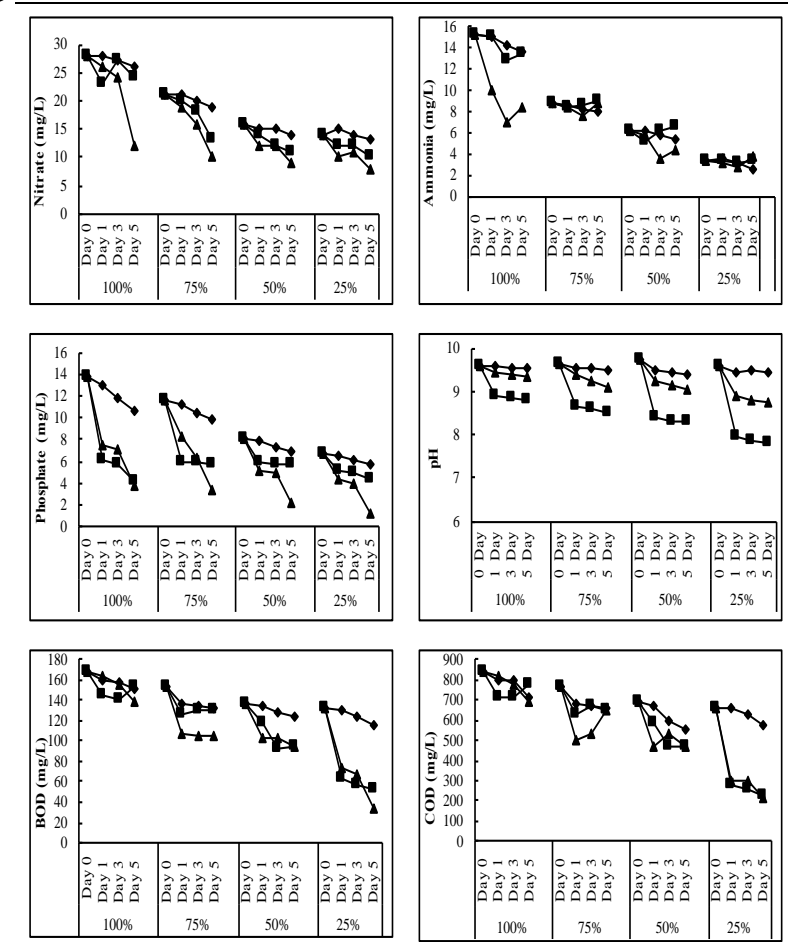

$\rightarrow$ Conttol $\rightarrow$ L.minor $\rightarrow$ A.pintinata

Fig. 5: Characteristic of Water Quality Throughout the 5-Day Phytotoxicity Test.

It is a toxic substance commonly found in POME. Ammonium intake is very important for the treatment of POME, in which ammonium is the primary form of nitrogen. The results of this study show that ammonia can be partially removed from treated POME using both species. A. pinnata was capable of removing ammonia from 14.3 to $7 \mathrm{mg} / \mathrm{L}$ which is $51.0 \%$ reduction compared with the control within 3 days in $100 \%$ treated POME as shown in Figure 5. The extraction rate of $\mathrm{NH}_{4}-\mathrm{N}$ after 5 days in all dilution solutions by $L$. minor was less favorable, only $9.8 \%$ removal in $100 \%$ treated POME. The ammonia concentration showed increment after 3 day of cultivation for $75 \%, 50 \%$ and $25 \%$ treated POME. The $\mathrm{NH}_{4}-\mathrm{N}$ concentrations at $50 \%$ and $25 \%$ treated POME increased significantly and reached 3.4 and $3.8 \mathrm{mg} / \mathrm{L}$ at the end of 5 days, respectively for A pinnata. This was mainly attributed to the breakdown of duckweed tissue, which was degraded by bacteria and exoenzymes, and eventually released $\mathrm{NH}_{4}^{+}$[42]. Duckweed deliberately absorbs ammonia from nitrites due to the nitrogen content in ammonium forms that is directly altered to plant proteins [54]. Due to the huge potential for wastewater treatment, duckweed is given the opportunity to increase the future through genetic engineering. The simple protocol for transferring gene to minor L. minor has been shown to produce more specific nutrients or other pollutants [55]. If the ammonia content in the water supply is too high, it can be very toxic to humans. [29] studied the nitrogen extraction by $L$. minor and found that these species growing in a 1:1 mixture of $\mathrm{NH}_{4}{ }^{+}$and $\mathrm{NO}_{3}{ }^{-}$preferably took ammonia against nitrate particularly in low nitrogen availability. Excessive ammonium speeds up eutrophication in the open pool and produces nitrate formation when released into underground water. Therefore, it is vital to remove it from wastewater.

[56] reported that floating plants such as Lemna sp. requires high concentration of phosphorus to grow in water. [57] also found that Lemna consistently released the largest amount of ammonia and phosphorus from storm water within 8 weeks. During the 5-day exposure, the phosphate from the treated POME solution was used by $A$. pinnata and $L$. minor for growth and its concentration was reduced $65.4 \%$ to $3.7 \mathrm{mg} / \mathrm{L}$ and $61.4 \%$ to $4.13 \mathrm{mg} / \mathrm{L}$ at the end of 
the trial for $100 \%$ treated POME due to the absorption and adsorption or direct taken by plants [58], compared with the phosphate concentration in the control which was only $10.7 \mathrm{mg} / \mathrm{L}$. There is a slight drop in phosphate levels in the treated POME in the early stages when the duckweeds grew with the abundance of more phosphate yields [57]. The decrease of phosphate in the 75\% treated POME was less for both plants due to lack of phosphate in the diluted solution. A more significant decrease can be seen in $A$. pinnata compared to L. minor in all POME concentrations.

The $\mathrm{pH}$ in treated POME for both plants on day zero was slightly alkaline conditions at $\mathrm{pH} 9.56$ and decreased gradually towards neutral conditions due to the release of hydrogen ions when ammonia was converted to nitrates [60]. The $\mathrm{pH}$ in 25\% POME concentration for L. minor decreased $17.3 \%$ to $\mathrm{pH} 7.8$ in 5 days compared to the value of $\mathrm{pH} 9.43$ for the control plant. The highest $\mathrm{pH}$ drop for A. pinnata occurred in the 25\% treated POME of 0.67 which is $7.1 \%$ drop compared to $100 \%$ treated POME which is only 0.20 drop on day 5. [51] , and, [60] reported the reduction in alkalinity values from and $\mathrm{pH} 8.9$ to $\mathrm{pH} 7.7$ for L. minor. [53] stated that reduction of $\mathrm{pH}$ at all points can be attributed to the fact that ammonia and nitrate can be reduced by this study. This is because the absorption of ammonia and nitrogen compounds usually promotes biological responses that produce hydrogen ions contributing to lower $\mathrm{pH}$ [61]. $\mathrm{pH}$ reduction is also the reason why ammonia, phosphate and nitrate can also be reduced [54].

In this study, COD and BOD contents were also investigated to identify the ability of $A$. pinnata and $L$. minor as phytoremediation plants to improve the quality of treated POME. POME contains high COD and BOD concentrations of organic pollutants that must be removed before POME can be released into the environment. The results of this study show that both $L$. minor and A. pinnata can reduce organic pollutants from treated POME for all POME concentrations within the 5-day exposure. The maximum removals of $63.0 \%$ and $61.0 \%$ for COD were observed in the $25 \%$ treated POME with final COD concentrations were $364 \mathrm{mg} / \mathrm{L}$ and 352 $\mathrm{mg} / \mathrm{L}$ for $A$. pinnata and $L$. minor respectively. In addition, the removal of BOD was $70.5 \%$ and $54.0 \%$ with final readings were $34 \mathrm{mg} / \mathrm{L}$ and $53 \mathrm{mg} / \mathrm{L}$ for $A$. pinnata and L. minor respectively, compared to the control of $115 \mathrm{mg} / \mathrm{L}$. While, an increase in COD and BOD readings can be observed for both plants in $100 \%$ and $75 \%$ POME concentrations. This is because on the fifth day, the crop had died entirely and, in this case, the photosynthesis process had stopped and no oxygen can be supplied to the solution [56]. In the early stages when plants began to grow and spread, POME treated with plants showed a greater amount of reduction in BOD [28]. A study by [62] also showed a reduction of COD and BOD for treating wastewater from chicken farm using A. pinnata. Another study conducted by [63], the reduction of COD and BOD was very significant using A. filiculas with $94.6 \%$ and $74 \%$ removal, respectively, in treating wastewater from the textile factory. Other study by [48] has also shown that $L$. minor can reduce COD and BOD in synthetic wastewater showing a significant reduction of $92.2 \%$ and $94.7 \%$. [64] reported that COD removal was in the range of $70-80 \%$ in discharge duckweed system.

\section{Conclusion}

Among the four different dilutions of treated POME, L. minor displayed higher tolerance and survival level compared to A. pinnata, $95 \%$ of L. minor remained fresh and green even in the $100 \%$ treated POME. However, A. pinnata mostly died at the end of 5day exposure even in the lowest dilution $(25 \%)$ of treated POME. Through this physical observation, it could be concluded that $L$. minor is a fern that is able to grow in treated POME containing high nutrient. This study was preceded to analyze the efficiency of L. minor and A. pinnata to remove nutrients and organic content from treated POME. A. pinnata had removed 53.8\%, 51.0\%, $65.4 \%, 70.5 \%$ and $63.0 \%$ respectively for COD, BOD, ammonia, phosphate and nitrates with the final effluent concentrations reached $12 \mathrm{mg} / \mathrm{L}, 7 \mathrm{mg} / \mathrm{L}, 3.70 \mathrm{mg} / \mathrm{L}, 212 \mathrm{mg} / \mathrm{L}$ and $34 \mathrm{mg} / \mathrm{L}$ in
$25 \%$ treatment POME concentrations for. Compared to A. pinnata, L. minor could only remove in average $31.6 \% \mathrm{NO}_{3}^{-}, 9.8 \% \mathrm{NH}_{4}-\mathrm{N}$ $61.4 \% \mathrm{PO}_{4}{ }^{3-}, 17.3 \% \mathrm{pH}, 54.0 \% \mathrm{BOD}_{5}$ and $61.0 \% \mathrm{COD}$ in all dilutions of treated POME with the respective final effluents as 13 $\mathrm{mg} / \mathrm{L}, 12.8 \mathrm{mg} / \mathrm{L}, 4.13 \mathrm{mg} / \mathrm{L}, 224 \mathrm{mg} / \mathrm{L}, 53 \mathrm{mg} / \mathrm{L}$, respectively. On overall, it can be concluded that A. pinnata works well in the treatment of treated POME compared to L. minor in terms of water quality although $L$. minor has a strong resistance in the high content of nutrients and organic carbon. Further study will be carried out to balance out the potential of phytoremediation and also the survival and tolerance of the plant species for the sustainability of the animal feed.

\section{Acknowledgement}

The authors would like to thank Tasik Chini Research Centre, Universiti Kebangsaan Malaysia (UKM) and the Ministry of Higher Education, Malaysia, for supporting this project through DIP-2017-022.

\section{References}

[1] Utusan Melayu (Malaysia) Berhad, Utusan Online 2016 http://m.utusan.com.my/berita/nasional/malaysia-kekal-pengeluarutama-minyak-sawit-dunia-1.394220 (13 Oct 2016).

[2] Malaysian National News Agency (, BERNAMA) http://www.bernama.com/bernama/v8/bm/bu/newsbusiness.php?id $=1319847$ (14 January 2017).

[3] DEPARTMENT OF STATISTICS MALAYSIA (DOSM) 2016 https://www.dosm.gov.my/v1/index.php?r=column/pdfPrev\&id=T2 Z3NkhLSFk2VjZ5dkdUL1JQUGs4dz09 (30 Disember 2016).

[4] Ahmad, A.L., Ismail, S. and Bhatia, S., 2003. Water recycling from palm oil mill effluent (POME) using membrane technology. Desalination, 157(1-3), https://doi.org/10.1016/S0011-9164(03)00387-4.

[5] Aziz M.A, H. Haris, Faten Ahada M.A., 2015. Treatment of palm oil mill effluent (POME) using membrane bioreactor. Malaysian Journal of Analytical Sciences, 19(3), pp.463-471.

[6] Mohammed, R.R. and Chong, M.F., 2014. Treatment and decolorization of biologically treated Palm Oil Mill Effluent (POME) using banana peel as novel biosorbent. Journal of Environmental Management, 132, pp. 237-249. https://doi.org/10.1016/j.jenvman.2013.11.031.

[7] Nwuche, C.O., Aoyagi, H. and Ogbonna, J.C., 2014. Treatment of Palm Oil Mill Effluent by a Microbial Consortium Developed from Compost Soils. International scholarly research notices,. Vol 2014, pp. 8 .

[8] Erakhrumen, Andrew, A., 2007. Phytoremediation: an environmentally sound technology for pollution prevention, control and remediation in developing countries. Educational Research and Reviews, 2(7), pp. 151-156.

[9] Titah, H.S., Abdullah, S.R.S., Mushrifah, I., Anuar, N., Basri, H. and Mukhlisin, M., 2013. Effect of applying rhizobacteria and fertilizer on the growth of Ludwigia octovalvis for arsenic uptake and accumulation in phytoremediation. Ecological Engineering, 58, pp.303-313. https://doi.org/10.1016/j.ecoleng.2013.07.018.

[10] Tangahu, B.V., Abdullah, S.R.S., Basri, H., Idris, M., Anuar, N. and Mukhlisin, M., 2013. Phytoremediation of wastewater containing lead $(\mathrm{Pb})$ in pilot reed bed using Scirpus grossus. International Journal of Phytoremediation, 15(7), pp. 663 676. https://doi.org/10.1080/15226514.2012.723069.

[11] Iatrou, E.I., Stasinakis, A.S. and Aloupi, M., 2015. Cultivating duckweed Lemna minor in urine and treated domestic wastewater for simultaneous biomass production and removal of nutrients and antimicrobials. Ecological Engineering, 84, pp.632-639 https://doi.org/10.1016/j.ecoleng.2015.09.071.

[12] Filbin, G.J. and Hough, R.A., 1985. Photosynthesis, photorespiration, and productivity in Lemna minor L. Limnology and oceanography, 30(2), pp.322-334. https://doi.org/10.4319/lo.1985.30.2.0322

[13] Bañuelos, G.S., Vickerman, D.B., Trumble, J.T., Shannon, M.C., Davis, C.D., Finley, J.W. and Mayland, H.F., 2002. Biotransfer possibilities of selenium from plants used in phytoremediation. International Journal of Phytoremediation, 4(4), pp.315-329. https://doi.org/10.1080/15226510208500090. 
[14] Siti Kamariah M. S. and Nastaein.Q., 2017. Phytoremediation Potential of Palm Oil Mill Effluent by Constructed Wetland Treatment. Engineering Heritage Journal, 1(1), pp.49-54. https://doi.org/10.26480/gwk.01.2017.49.54.

[15] Hadiyanto, M.C., Soetrisnanto, D. and Christwardhana, M., 2013. Phytoremediations of palm oil mill effluent (POME) by using aquatic plants and microalgae for biomass production. Journal of Environmental Science and Technology, 6(2), pp. 79-90. https://doi.org/10.3923/jest.2013.79.90.

[16] Darajeh, N., Idris, A., Truong, P., Abdul Aziz, A., Abu Bakar, R. and Che Man, H., 2014. Phytoremediation potential of vetiver system technology for improving the quality of palm oil mill effluent. Advances in Materials Science and Engineering, 2014, pp. 10

[17] Hadiyanto, H., Soetrisnanto, D. and Christwardhana, M., 2014. Phytoremediation of palm oil mill effluent using pistia stratiotes plant and algae spirulina sp for biomass production. International Journal of Engineering-Transactions C: Aspects, 27(12), pp. 18091814.

[18] Hamzah, M.F., 2014. Phytoremediation of Palm Oil Mill Final Discharge Wastewater Using Selected Aquatic Macrophytes (Doctoral Dissertation, Faculty of Science and Mathematics, Universiti Pendidikan Sultan Idris).

[19] Chukwunonso, O.I., Fauziah, S.H. and Redzwan, G., 2014. The Utilization of Water Hyacinth (Eichhorniacrassipes) as Aquatic Macrophage Treatment System (AMATS) in Phytoremediation for Palm Oil Mill Effluent (POME). International Journal of Sciences: Basic and Applied Research (IJSBAR), 13, pp. 31-47.

[20] Akinbile, C.O., Ogunrinde, T.A., Che bt Man, H. and Aziz, H.A. 2016. Phytoremediation of domestic wastewaters in free water surface constructed wetlands using Azolla pinnata. International Journal of Phytoremediation, 18(1), pp.54-61 https://doi.org/10.1080/15226514.2015.1058330.

[21] Rai, P.K., 2008. Phytoremediation of $\mathrm{Hg}$ and $\mathrm{Cd}$ from industrial effluents using an aquatic free floating macrophyte Azolla pinnata. International Journal of Phytoremediation, 10(5), pp. 430439 https://doi.org/10.1080/15226510802100606.

[22] Forni, C., Chen, J., Tancioni, L. and Caiola, M.G., 2001a. Evaluation of the fern Azolla for growth, nitrogen and phosphorus removal from wastewater. Water Research, 35(6), pp.1592-1598. https://doi.org/10.1016/S0043-1354(00)00396-1.

[23] Shammout, M.A.W., Oran, S. and Fayyad, M., 2008. The application of duckweed (Lemna sp.) in wastewater treatment in Jordan. International Journal of Environment and Pollution, 33(1), pp. 110-120. https://doi.org/10.1504/IJEP.2008.018472.

[24] Haustetn, A., Gilman, R.H., Skillicorn, P.W., Vergara, V., Guevara, V. and Gastanaduy, A., 1990. Duckweed, a useful strategy for feeding chickens: performance of layers fed with sewage-grown Lemnacea species. Poultry Science, 69(11), pp.1835-1844 https://doi.org/10.3382/ps.0691835.

[25] Hammer, D.A. ed., 1989. Constructed wetlands for wastewater treatment: municipal, industrial and agricultural. CRC Press.

[26] Oron, G. and Willers, H., 1988. Effect of wastes quality on treatment efficiency with duckweed. In Water Pollution Research and Control Brighton (pp. 639-645) https://doi.org/10.1016/B978$1-4832-8439-2.50065-1$

[27] Leterme, P., Londoño, A.M., Ordoñez, D.C., Rosales, A., Estrada, F., Bindelle, J. and Buldgen, A., 2010. Nutritional value and intake of aquatic ferns (Azolla filiculoides Lam. and Salvinia molesta Mitchell.) in sows. Animal feed science and technology, 155(1), pp.55-64 https://doi.org/10.1016/j.anifeedsci.2009.10.002

[28] Chaudhary, E. and Sharma, P., 2014. Use of Duckweed in Wastewater Treatment. International Journal of Innovative Research in Science, Engineering and Technology, 3(6), pp.1362213624

[29] Cedergreen, N. and Madsen, T.V., 2002. Nitrogen uptake by the floating macrophyte Lemna minor. New Phytologist, 155(2), pp.285-292. https://doi.org/10.1046/j.1469-8137.2002.00463.x.

[30] Alaerts, G.J., Mahbubar, R. and Kelderman, P., 1996. Performance analysis of a full-scale duckweed-covered sewage lagoon. Water Research, 30(4), pp.843-852 https://doi.org/10.1016/00431354(95)00234-0.

[31] Vermaat, J.E. and Hanif, M.K., 1998. Performance of common duckweed species (Lemnaceae) and the waterfern Azolla filiculoides on different types of waste water. Water Research, 32(9), pp. 2569-2576 https://doi.org/10.1016/S00431354(98)00037-2.

[32] Haarstad, K., Bavor, H.J. and Mæhlum, T., 2011. Organic and metallic pollutants in water treatment and natural wetlands: a review. Water Science and Technology, 65(1), pp.76-99 https://doi.org/10.2166/wst.2011.831.

[33] Wagner, G.M., 1997. Azolla: a review of its biology and utilization. The Botanical Review, 63(1), pp. 1-26 https://doi.org/10.1007/BF02857915.

[34] Pabby A, Prasanna R, Singh PK., 2003. Azolla-Anabaena symbiosis from traditional agricultural to biotechnology. Indian Journal Of Biotechnology. Vol 2, pp. 26-37.

[35] Shi, D.J. and Hall, D.O., 1988. TheAzolla-Anabaena association: Historical perspective, symbiosis and energy metabolism. The Botanical Review, 54(4), pp. 353-386 https://doi.org/10.1007/BF02858416.

[36] Peters, G.A. and Meeks, J.C., 1989. The Azolla-Anabaena symbiosis: basic biology. Annual Review of Plant Biology, 40(1), pp. 193-210. https://doi.org/10.1146/annurev.pp.40.060189.001205.

[37] De Macale, M.A.R. and Vlek, P.L., 2004. The role of Azolla cover in improving the nitrogen use efficiency of lowland rice. Plant and Soil, 263(1), https://doi.org/10.1023/B:PLSO.0000047742.67467.50.

[38] Singh, B., Meena, G.S., Meena, K.C., Meena, R.K., Singh, B. and Indoria, D., 2017. Effect of a Wonder Herb Azolla on Buffaloes Milk Yield. Int. J. Curr. Microbiol. App. Sci, 6(11), pp. 1059-1066 https://doi.org/10.20546/ijcmas.2017.611.124.

[39] Senthilkumar, S. and Manivannan, C., 2016. Adoption of Azolla Cultivation Technology in the Farmers' Field: An Analysis. International journal of science, Environment and Technology, Vol. 5, pp. 3081-3087

[40] Saha, P., Banerjee, A. and Sarkar, S., 2015. Phytoremediation potential of Duckweed (Lemna minor L.) on steel wastewater. International Journal of Phytoremediation, 17(6), pp.589-596. https://doi.org/10.1080/15226514.2014.950410.

[41] Mohammed, R.R., Ketabchi, M.R. and McKay, G., 2014. Combined magnetic field and adsorption process for treatment of biologically treated palm oil mill effluent (POME). Chemical Engineering Journal, 243, pp. 31-42 https://doi.org/10.1016/j.cej.2013.12.084.

[42] Liu, C., Dai, Z. and Sun, H., 2017. Potential of duckweed (Lemna minor) for removal of nitrogen and phosphorus from water under salt stress. Journal of Environmental Management, 187, pp.497-503 https://doi.org/10.1016/j.jenvman.2016.11.006.

[43] Singh, V.K. and Singh, J., 2006. Toxicity of industrial wastewater to the aquatic plant Lemna minor L. Journal of Environmental Biology, 37(2), pp. 385-390.

[44] Cedergreen, N. and Madsen, T.V., 2004. Light regulation of root and leaf NO3- uptake and reduction in the floating macrophyte Lemna minor. New Phytologist, 161(2), pp.449-457. https://doi.org/10.1046/j.1469-8137.2003.00936.x.

[45] Ziegler, P., Sree, K.S. and Appenroth, K.J., 2016. Duckweeds for water remediation and toxicity testing. Toxicological \& Environmental Chemistry, 98(10), pp. 1127-1154. https://doi.org/10.1080/02772248.2015.1094701

[46] Appenroth, K.J., Krech, K., Keresztes, A., Fischer, W. and Koloczek, H., 2010. Effects of nickel on the chloroplasts of the duckweeds Spirodela polyrhiza and Lemna minor and their possible use in biomonitoring and phytoremediation. Chemosphere, 78(3), pp.216-223. https://doi.org/10.1016/j.chemosphere.2009.11.007.

[47] Ben-shalom, M., Shandalov, S., Brenner, A. and Oron, G., 2014. The effect of aeration and effluent recycling on domestic wastewater treatment in a pilot-plant system of duckweed ponds. Water Science and Technology, 69(2), pp. 350-357. https://doi.org/10.2166/wst.2013.720.

[48] Muradov, N., Taha, M., Miranda, A.F., Kadali, K., Gujar, A., Rochfort, S., Stevenson, T., Ball, A.S. and Mouradov, A., 2014 Dual application of duckweed and azolla plants for wastewater treatment and renewable fuels and petrochemicals production. Biotechnology for biofuels, 7(1), pp. 30 https://doi.org/10.1186/1754-6834-7-30.

[49] Bhuvaneshwari, K. and Singh, P.K., 2015. Response of nitrogenfixing water fern Azolla biofertilization to rice crop. 3 Biotech, 5(4) pp.523-529.

[50] Kamyab, H., Chelliapan, S., Din, M.F.M., Shahbazian-Yassar, R., Rezania, S., Khademi, T., Kumar, A. and Azimi, M., 2017. Evaluation of Lemna minor and Chlamydomonas to treat palm oil mill effluent and fertilizer production. Journal of Water Process Engineering, 17, https://doi.org/10.1016/j.jwpe.2017.04.007

229-236

[51] Ozengin, N. and Elmaci, A., 2007. Performance of Duckweed (Lemna minor L.) on different types of wastewater treatment. Journal of Environmental Biology, 28(2), pp. 307-314. 
[52] Al-Baldawi, I.A., Abdullah, S.R.S., Suja, F., Anuar, N. and Idris, M., 2012, May. Preliminary test of hydrocarbon exposure on Azolla pinnata in phytoremediation process. In International conference on environment, Energy and biotechnology IPCBEE (Vol. 33, pp. 244247).

[53] Forni, C., Nicolai, M.A. and D'Egidio, M.G., 2001b. Potential Of The Small Aquatic Plans Azolla And Lemna For Nitrogenous Compounds Removal From Wastewater. WIT Transactions on Ecology and the Environment, 49. pp. 1743-3541.

[54] El-Shafai, S.A., El-Gohary, F.A., Nasr, F.A., Van Der Steen, N.P. and Gijzen, H.J., 2007. Nutrient recovery from domestic wastewater using a UASB-duckweed ponds system. Bioresource Technology, 98(4), https://doi.org/10.1016/j.biortech.2006.03.011.

[55] Cheng, J., Landesman, L., Bergmann, B.A., Classen, J.J., Howard, J.W. and Yamamoto, Y.T., 2002. Nutrient removal from swine lagoon liquid by Lemna minor 8627. Transactions of the ASAE, 45(4), p.1003 https://doi.org/10.13031/2013.9953.

[56] Landolt, E. and Kandeler, R., 1987. Biosystematic investigations in the family of duckweeds (Lemnaceae)(vol. 4). The family of Lemnaceae-a monographic study, 2, pp.211-34.

[57] Perniel, M., Ruan, R. and Martinez, B., 1998. Nutrient removal from a stormwater detention pond using duckweed. Applied engineering in agriculture, 14(6), pp. 605-609 https://doi.org/10.13031/2013.19429.

[58] Sooknah, R.D. and Wilkie, A.C., 2004. Nutrient removal by floating aquatic macrophytes cultured in anaerobically digested flushed dairy manure wastewater. Ecological Engineering, 22(1), pp. 27-42. https://doi.org/10.1016/j.ecoleng.2004.01.004.

[59] Priya, A., Avishek, K. and Pathak, G., 2012. Assessing the potentials of Lemna minor in the treatment of domestic wastewater at pilot scale. Environmental monitoring and assessment, 184(7), pp 4301-4307 https://doi.org/10.1007/s10661-011-2265-6.

[60] Azeez, N.M. and Sabbar, A.A., 2012. Efficiency Of Duckweed (Lemna Minor L.) In Phytotreatment Of Wastewater Pollutants From Basrah Oil Refinery. Journal of Applied Phytotechnology in Environmental Sanitation, 1 (4): 163-172.

[61] Taylor, D.J., Green, N.P.O. and Stout, G.W., (1997). Biological Sciences, R. Soper. University Press.

[62] Jangwattana, R. and Iwai, C.B., 2010. Using Azolla pinnata for wastewater treatment from poultry farm. International Journal of Environmental and Rural Development, 1(2), pp.23-27.

[63] Rizwana, M., Darshan, M. and Nilesh, D., 2014. Phytoremediation of textile waste water using potential wetland plant: eco sustainable approach. International journal of interdisciplinary and Multidisciplinary Studies (IJIMS), 1(4), pp. 130-138.

[64] Pandey, M., 2001. Duckweed based wastewater treatment. Invention Intelligence. 